\title{
Initial Results of a Doctorate in Medical Sciences Program at a Regional University
}

\author{
Resultados Iniciales de un Programa de Doctorado \\ en Ciencias Médicas de una Universidad
}

\author{
Carlos Manterola ${ }^{* * *, * * *, * * * * ;}$; Tamara Otzen ${ }^{* * *, * * *, * * * * *}$; Ricardo Cartes-Velásquez ${ }^{* * *, * * * * * * ;}$ \\ Mariano del Sol ${ }^{* *, * * *}$, Sergio Olate ${ }^{* *, * * *}$; Fernando Romero ${ }^{* * * *}$ \& Paula Astudillo, ${ }^{*, * * *}$
}

MANTEROLA, C.; OTZEN, T. ; CARTES-VELÁSQUEZ, R.; DEL SOL, M.; OLATE, S.; ROMERO, F. \& ASTUDILLO, P. Initial results of a doctorate in medical sciences program in a regional university. Int. J. Morphol., 34(3):1169-1175, 2016.

SUMMARY: The number of doctoral programs in the biomedical field has risen in recent decades, but with a concentration in Santiago and little expansion into the provinces. The aim of this article is to describe the initial results obtained by the Doctorate in Medical Sciences program of the Universidad de La Frontera, Chile. Observational study, conducted in the Department of Surgery at the Universidad de La Frontera, Chile. All cohorts in the program from 2008 to 2015 were included. The outcome variables were: Graduation rate and scientific productivity of the graduates (WoS and SciELO publications). Other variables of interest were: academic faculty productivity (WoS and SciELO publications), and characteristics of students who entered the program (age, sex, origin, profession, previous graduate training and number of years of formal university education). Descriptive statistics were applied. During the evaluation period, of a total of 17 qualified, 8 doctorates have been granted (1.6 per year), a graduation rate of $47.1 \%$. The research productivity for 2010-2015 was 14.1 publications per graduate (8.4 WoS and 5.7 SciELO) and 43.8 publications per academic (41.2 WoS and 2.6 SciELO). In the period, 55 professionals applied and 27 were accepted (49.1\% rate acceptance). Initial results of the Doctorate in Medical Sciences program of the Universidad de La Frontera, Chile are presented.

KEY WORDS: Education, Graduate; Education, Medical, Graduate; Education, Dental, Graduate; Education, Medical; Education, Medical, Continuing; Doctorate programs; Ph.D. programs; Postdoctoral programs.

\section{INTRODUCTION}

The development of biosciences and medicine in recent decades has had a positive impact on human life. The ongoing emergence of new technologies in the area of diagnosis and treatment have a direct effect on life expectancy at birth, the population's quality of life, epidemiological transition, health economics, and so forth. (Moses et al., 2015). Clinical research, however, requires ever more professionals able to investigate diseases from their molecular base to the clinical manifestations (Rosenberg, 1999; Vujaklija et al., 2010). If to this we add the increasingly common practice of evidence-based medicine (Manterola, 2009), without a doubt it will be essential or at least highly advisable in the coming decades to have these types of competencies and abilities in order to continue conducting medical research. Paradoxically, teaching medicine in
Chilean universities has had little success in producing doctors interested in filling this void.

The Doctorate in Medical Sciences program at the Universidad de La Frontera (DCM-UFRO) began from the consolidation of the Master's in Medical Sciences specializing in Surgery, which was created in 2004 and is currently accredited by the accrediting agency ADC for 6 years (20132019). The faculty of the DCM-UFRO is comprised of professors belonging to the UFRO Faculties of Medicine and Dentistry, with the latter having been the Department of Comprehensive Dentistry until 2012. The DCM-UFRO grants the degree of Doctor in Medical Sciences after the approval of mandatory subjects, electives, and the planning and implementation of a research project (degree thesis).

* Departamento de Cirugía y Traumatología, Universidad de La Frontera, Temuco, Chile.

* Centro de Estudios Morfológicos y Quirúrgicos (CEMyQ), Universidad de La Frontera, Temuco, Chile.

**** Programa de Doctorado en Ciencias Médicas, Universidad de La Frontera, Temuco, Chile.

**** Centro de Investigaciones Biomédicas, Universidad Autónoma de Chile, Chile.

****** Universidad de Tarapacá, Chile.

${ }^{* * * * * *}$ Facultad de Odontología, Universidad de Concepción, Concepción, Chile. 
The aim of the program is to produce top-quality graduates, critical thinkers able to lead scientific research teams and work in an area of specialization with technical dependability and creativity; this way, they can conduct research in medical sciences, also with the facilities to delve more deeply into the field in an academic capacity, generating new knowledge or solving high-priority problems. The program endeavors to train investigators who, through their respective theses, lines of research and publications can generate knowledge, thus contributing to the advancement of knowledge in the different areas of medical sciences. It is defined as a cross-sectional program (for all areas of medical sciences, including basic sciences), with a strong emphasis on the methodological aspects.

The DCM-UFRO was approved by all the associated bodies of the University in 2007, with the first cohort of students entering in 2008. In 2013 it was subject to accreditation by the National Accreditation Commission (CNA) and was accredited for two years and re-accredited at the end of 2015.

This article was written following the MInCir initiative for the reporting of descriptive observational studies (Manterola \& Astudillo, 2013).

The aim is to describe the initial results obtained by the DCM-UFRO program.

\section{MATERIAL AND METHOD}

Design: Descriptive observational.

Center: Department of Surgery and the Center for Excellence in Morphological and Surgical Studies (CEMyQ), Universidad de La Frontera.

Participants: All the program cohorts from 2008 to 2015 inclusively were incorporated. There were no exclusion criteria.

Variables: The outcome variables were the graduation rate and productivity of the graduates in the study period, measured by publications in the Web of Science (WoS) and Scientific Electronic Library Online (SciELO) databases. Other variables of interest were: productivity of the academic faculty (publications in the WoS and SciELO databases); and characteristics of the students in the program (age, sex, origin, profession, previous graduate education, number of years of formal university education).

Curriculum: The curriculum consists of a total of 137 credits, 62 for subjects and 75 for the thesis (an intermediate Master's is not considered). It lasts a minimum of 6 semesters, with part-time of 22 hours per week of independent work, plus two and half days on-site once a month. The part-time schedule is only for the first two semesters, when most of the mandatory subjects take place. From the 3rd semester, the time students spend in the program gradually increases: the elective subjects, seminars and research units begin, and an external internship is undertaken ( 3 to 12 months in duration [according to the need imposed by the supervisor and thesis topic], full-time given the intensive nature of the work in a selected research center). The last 3 semesters are full-time exclusively for thesis work, which means an approximate total of 3,608 to 4,334 hours, depending on the duration of the external internship.

The program subjects are as follows: Foundations of Medical Sciences I and II, Foundations for Clinical Research I and II, Biostatistics I and II, Induction to the formulation of projects and presentation of results, Qualitative analysis of biomedical literature, Bioethics, Experimentation with biological material, Electives 1 and 2, seminars and research units, and degree thesis.

The program has several lines of research, which are placed in 11 groups: Bibliometrics, Reproductive biology, Molecular biology, Diseases of the digestive apparatus, Pharmacogenetics and cardiovascular genetics, Research methodology, Statistical modeling (distribution theory), Morphometrics, Neurosciences, Maxillofacial pathology, and Systematic reviews.

Follow-up: A follow-up was done of the graduates to ascertain their employment situation once they had concluded their program and returned to work full-time.

Statistics: Using the Stata 11.0 statistics package, an exploratory data analysis was made of the data and descriptive statistics were applied with calculation of percentages, measures of central tendency and dispersion.

Ethical principles: Identity of all the participants (students, graduates and academics) was masked by coding each of them.

\section{RESULTS}

During the assessment period, of a total of 17 students who approved their Qualification Exam, 8 doctorates have been granted, meaning a graduation rate of $47.1 \%$ (1.6 graduates per year). Of these, $75.0 \%$ are undertaking academic activities in their originating institutions, thus 
achieving total reintegration. The two remaining $(25.0 \%)$ have been accepted into a postdoctoral scholarship program in our institution; this program began three years ago, and has admitted 2 doctorate holders to date, who with a foundation in a performance program, have applied to financing sources and are publishing research in journals indexed in the WoS and SciELO databases.

The graduates' productivity adds up to an average of 8.4 WoS publications and 5.7 SciELO publications per graduate in the period 2010-2015 (6 years). This is equivalent to an average of 14.1 publications per graduate in the period (2.4 publications per graduate per year). See Table I.

Table I. Productivity of the graduates in the WoS and SciELO databases (2010-2015). ( $\mathrm{N}=8)$

\begin{tabular}{lccc}
\hline Graduate & WoS (ISI) & SciELO & Total \\
\hline 1 & 5 & 0 & 5 \\
2 & 5 & 0 & 5 \\
3 & 11 & 5 & 16 \\
4 & 13 & 30 & 43 \\
5 & 7 & 3 & 10 \\
6 & 17 & 0 & 17 \\
7 & 3 & 0 & 3 \\
8 & 6 & 8 & 14 \\
Total & $\mathbf{6 7}$ & $\mathbf{4 6}$ & $\mathbf{1 1 3}$ \\
Mean & $\mathbf{8 . 4}$ & $\mathbf{5 . 8}$ & $\mathbf{1 4 . 1}$ \\
Mean/ year & $\mathbf{1 . 4}$ & $\mathbf{1 . 0}$ & $\mathbf{2 . 4}$ \\
\hline
\end{tabular}

The academic faculty's productivity adds up to an average of $41.2 \mathrm{WoS}$ publications and 2.6 SciELO publications per academic in the 2010-2015 period, equivalent to an average of 43.8 indexed publications in the study period (7.3 publications per academic per year). See Table II.

Table II. Productivity of the academics in the WoS and SciELO databases $(2010-2015)$. $(\mathrm{N}=12)$

\begin{tabular}{lccc}
\hline Faculty member & WoS & SciELO & Total \\
\hline 1 & 22 & 1 & 23 \\
2 & 49 & 5 & 54 \\
3 & 46 & 10 & 56 \\
4 & 66 & 2 & 68 \\
5 & 70 & 9 & 79 \\
6 & 11 & 0 & 11 \\
7 & 99 & 0 & 99 \\
8 & 29 & 0 & 29 \\
9 & 7 & 2 & 9 \\
10 & 59 & 0 & 59 \\
11 & 23 & 0 & 23 \\
12 & 13 & 2 & 15 \\
Total & $\mathbf{4 9 4}$ & $\mathbf{3 1}$ & $\mathbf{5 2 5}$ \\
Mean & $\mathbf{4 . 2}$ & $\mathbf{2 . 5}$ & $\mathbf{4 3 . 8}$ \\
Mean/ year & $\mathbf{6 . 9}$ & $\mathbf{0 . 4}$ & $\mathbf{7 . 3}$ \\
\hline
\end{tabular}

In the study period, a total of 55 professionals applied to the DCM-UFRO program; 27 were accepted (49.1\% acceptance rate). The average age of the students was $29.0 \pm 18.4$ years; $51.9 \%$ were male. The average number of years of formal university studies was $10.0 \pm 4.2$ years; the most common professions were dentists and physicians ( 66.7 $\%) .63 \%$ of the students had a Master's degree and $22.2 \%$ a medical or dental specialty. Most of the students came from the Universidad de La Frontera and the Universidad de Concepción (48.2\%). Biodemographic variables and student characteristics are described in Tables III and IV.

Table III. Distribution of continuous variables of students in study period (2010-2015). ( $\mathrm{N}=27)$.

\begin{tabular}{lccc}
\hline Variable & Average \pm SD & Median & Minimum \\
\hline Age (years) & $29 \pm 18.4$ & 29,5 & $25-51$ \\
Education (years) & $10 \pm 4.2$ & 8 & $6-12$ \\
\hline $\begin{array}{l}\text { SD:Standard deviation } \\
\text { prior to program admission }\end{array}$ & Education:Years of formal university studies
\end{tabular}

Table IV. Distribution of categorical variables of students in study period (20102015). ( $\mathrm{N}=27)$.

\begin{tabular}{lcc}
\hline Variable & $\mathbf{N}^{\mathbf{0}}$ & $\mathbf{\%}$ \\
\hline Gender & & \\
Male & 14 & 51.9 \\
Female & 13 & 48.1 \\
Profession & & \\
Dentist & 12 & 44.4 \\
Physician & 6 & 22.3 \\
Physiotherapist & 3 & 11.1 \\
Pharmacist & 2 & 7.4 \\
Dietician & 1 & 3.7 \\
Medical technician & 1 & 3.7 \\
Psychologist & 1 & 3.7 \\
Statistician & 1 & 3.7 \\
Graduate studies* & & \\
Master's & 17 & 63.0 \\
Specializations $* *$ & 11 & 22.2 \\
Both *** & 5 & 18.5 \\
Neither & 4 & 14.8 \\
Origin **** & & \\
U. de La Frontera & 6 & 22.2 \\
U. Concepción & 6 & 22.2 \\
U. Talca & 4 & 14.8 \\
U. Austral & 3 & 11.1 \\
U. de Chile & 3 & 11.1 \\
Others ***** & 5 & 18.5 \\
\hline
\end{tabular}

*Graduate studies:Previous graduate education (the sum is greater than 27, as some had a specialty and a Master's degree). **Specialization:Medical or dental specialization. ***Both:Master's, medical or dental specialization and/or medical sub-specialization. $* * * *$ Origin:Institutional origin (originating academic center)****** Others:Universidades Finis Terrae, Autónoma, San Sebastián, Mayor and Santo Tomás. 
Four grants were obtained from the Chilean National Council for Scientific and Technological Research (CONICYT) from 4 applicants (100\%) in just one round of competition (2014), and one of the program's theses was conducted with financing from the National Fund for Health Research and Development (FONIS).

To date, students in the program have visited the following centers during their external internship: UAB, Spain; USP, UNIFESP and UNICAMP, Brazil; University of Queensland, Australia; and the Center for Mind and Brain at the University of California, USA.

The program has 5 international agreements in effect. One double degree (Federal University of Sao Paulo [UNIFESP], Brazil), three external internships (UNIFESP, University of Sao Paulo [USP], and University of Campinas [UNICAMP], Brazil; Universitat Autònoma de Barcelona [UAB], Spain), and one with the Universidad Central de Ecuador (UCE), which accepts students from this institution into their program. In addition, there is a national agreement with the Universidad de Tarapacá (UTA) for conducting research and graduate activities through CEMyQ.

The Program is advertised through the website http:// www.med.ufro.cl/doccsmedicas, Twitter account @CsMedicasUFRO, and Facebook https:// www.facebook.com/CsMedicasUFRO.

\section{DISCUSSION}

The route to a doctorate can be long and fraught with difficulties, including periods of discouragement. Therefore, one of the most important things is that the experience be a pleasant one; this means deciding which of the different doctoral program options best fits the real interests of the potential applicant and are compatible with his/her needs. In order of importance these are: the search for the right supervisor, an appropriate research question, and the support of both the supervisor and fellow program participants (Gill et al., 2009).

However, in terms of national numbers, there is evidence that graduate enrollment in Chile has grown from 20,693 in 2007 to 46,806 in 2014; it has doubled in just 8 years. However, the enrollment for doctoral programs only grew from 3,029 to 4,925 in the same period, which represents only $10.5 \%$ of the total graduate enrollment in 2014 . On the other hand, of the 228 doctoral programs offered in 2014, the offer was concentrated in the areas of Sciences $(36 \%)$, Social Sciences $(15 \%)$ and Engineering (14\%), with the subgroup "Health and Social Services" representing only $7 \%$ of the total offering (CNA 2015), of which medical sciences are only $1.8 \%$ with just 4 active programs (Valdés et al., 2012).

Weaknesses the CNA recognizes with respect to the graduate system in Chile include: asymmetry in the coverage at regional level (57\% of accredited doctoral programs are in Santiago), a considerable offering of non-accredited programs, and an imbalance in the accreditation by disciplinary area, with science and technologies predominating with low coverage in the area of health. In addition, there is evidence that $70 \%$ of the doctoral program offerings were accredited in 2014 (161 programs); yet there were 67 non-accredited programs (30\%) in the same time period. What is more, 26.4 $\%$ of these programs were "outside the system" (Comisión Nacional de Acreditación CNA-Chile, 2015).

As mentioned in previous paragraphs, in Chile there are only 4 doctoral programs that carry the designation of "Medical Sciences" (Pontificia Universidad Católica de Chile, Universidad de Chile, Universidad de La Frontera and Universidad Austral de Chile) (Valdés et al.); however, we must mention the following in this regard:

1.The Universidad de Chile offers a program whose objective is to train a specialist physician or a doctorate in medical sciences. For 2016 the specialties available for this are: Internal medicine, Pediatrics, Adult Psychiatry, Pediatric and Adolescent Psychiatry, Surgery, Obstetrics and Gynecology, Neurology, Urology, Coloproctology and Otorhinolaryngology. The program lasts 6 years, 3 years of clinical training and 3 years of research. Once the thesis project is approved, the doctoral candidate is assigned a clinical tutor and a tutor in basic sciences to support the implementation of the thesis. The program is accredited for 6 years. No data could be obtained regarding the total number of graduates since its inception (1993), only information indicating that in recent years it has had an approximate average of awarding 4 doctorates per year (Universidad de Chile, 2015).

2. The Pontificia Universidad Católica de Chile's program is accredited for 7 years and has a nominal period of 3 years full-time. It has awarded 44 doctorates since its creation (1995), with an average of 2.2 per year. In the first stage, the student takes minimum advanced courses, specialized electives and leveling courses; then the candidate focuses on the doctoral thesis project (Pontificia Universidad Católica de Chile, 2015).

3.The program at the Universidad Austral de Chile is accredited for 3 years. Its objective is to train doctoral candidates who have the highest level of competencies in biomedical research for clinical or epidemiological purposes. Since its creation in 2010 it reports one graduate. Its website provides information only on the Committee, the Director and aim of 
the program (Universidad Austral de Chile, 2015).

Despite the existence of these 4 programs, however, graduation in the area is very low; consequently, it could be said that, not only is this number not enough, but on the contrary a major and real effort is needed to significantly increase advanced human capital in this area. This involves much lower costs than what is spent annually from the state coffers sending health care professional to centers in other countries, some of whom do not return, and others who upon their return do not find employment (Gonzalez \& Jiménez, 2014).

At the international level, there is evidence of the growth in the total number of biomedical doctorate holders, whereas the number of jobs in the faculties has remained steady, it has resulted in a decrease of teaching positions for these doctorates. Furthermore, in industry, the jobs for such professionals have increased, and in the future they could surpass the academic offering for them (Garrison \& Gherbi, 1998). This increase in the number of doctorates granted in recent decades in North America and Europe has not been balanced out by a similar increase in the number of academic positions (which has translated into a surfeit of postdoctorates); and one of the reasons cited, is the general perception that there is no alternative route to an academic career that is not through obtaining a degree, particularly a doctorate (Gould, 2000).

It may be this overpopulation of doctorates that has driven the creation of post-doctoral programs, which enable universities on the one hand to absorb this "qualified manpower", and on the other to benefit from financing (scholarships and competitive grants) and the generation of knowledge (publications) that this "advanced human capital" produces. These issues have been in evidence already for more than a decade (Korn, 2004, Benderly, 2005). It is also the case at the UFRO, which also decided years ago to bank on a system of post-doctoral scholarships associated with the different doctoral programs in the institution, obtaining interesting and profitable results.

One aspect of interest that doctorate holders in medical sciences should consider is their integration with the medical or dental degree. The existence of combined MD/PhD programs for physicians or DDS/PhD for dentists has been on offer in the United States for more than 50 years through the Medical Scientist Training Program of the National Institutes of Health (Jeffe \& Andriole, 2011; Bills et al., 2013; Jeffe et al., 2014; O'Mara et al., 2015). These programs have been imitated by other countries like Canada (Twa et al., 2015), Switzerland (Kuehnle et al., 2009) and Brazil (Oliveira et al.). The main motivation for such programs is to encourage the physicians' interest in science early on because in later stages competing with the interest in clinical work is practically impossible (Jeffe \& Andriole; Oliveira et al.; Menezes et al., 2015). Considering the differences between American and Chilean medical training, as well as the experience of the former with these combined programs, it seems feasible to explore an extracurricular integration during the first 5 years of the medical degree and that the most qualified students should enter a formal combined program of internship and doctorate of 5 to 6 years.

With respect to published figures, in our opinion it seems interesting to note the graduation rate, which with 47.1 $\%$ is similar to that of the programs for Biomedical Sciences, Microbiology and Neurosciences and Neurobiology (47.4; 47.1 and 46.2 respectively) reported by the National Academies Press (USS) (Lorden et al., 2011).

Finally, it seems to us that one of the novel features of the DCM-UFRO program has to do with curriculum flexibility, which has permitted the admission of professionals with a heavy work load like physicians and dentists. Nevertheless, a series of consultations about the program are only about that, with no actual application ever materializing because professionals in medical sciences are already teaching in the area, with a high undergraduate work load and financial responsibilities, and do not have the support of many universities for the time off and the authorization for these academics to continue their further graduate education (substitutions to cover the work schedule, particularly during thesis work, when students stay for long periods of time in our institution). Finally, it is only fair to comment that this program has the strength to collaborate in decentralizing graduate education in Chile, being under the auspices of a regional university located in the Region of La Araucanía.

Another novelty has to do with the double degree agreement with UNIFESP, active since 2013; this has allowed two of our 8 graduates $(25.0 \%)$ to be able to opt for the double doctoral degree (UFRO / UNIFESP). This interuniversity cooperation initiative that the UNIFESP has also developed with some European universities resembles the "I.O. PhD Research Program" between the universities of the Maastricht and Utrecht with the Italian Children's Hospital in Alessandria (Bellissima et al., 2011).

In conclusion, the initial results of the Doctorate in Medical Sciences program at the Universidad de La Frontera are presented, which emphasize the graduation and acceptance rate, and the scientific productivity of both the graduates and the academic faculty. We are aware, however, of the need to continue improving all the indicators measured and reported in this manuscript. 
MANTEROLA, C.; OTZEN, T. ; CARTES-VElÁSQUEZ, R.; DEL SOL, M.; OLATE, S.; ROMERO, F. \& ASTUDILLO, P. Resultados iniciales de un programa de doctorado en ciencias médicas de una universidad regional. Int. J. Morphol., 34(3):1169-1175, 2016 .

RESUMEN: El número de programas de doctorado en el área biomédica ha crecido en las últimas décadas, aunque la mayoría se concentra en Santiago, con un escaso desarrollo en regiones. El objetivo de este artículo es describir los resultados iniciales obtenidos por el programa de Doctorado en Ciencias Médicas de la Universidad de La Frontera. Estudio observacional, descriptivo; realizado en el Departamento de Cirugía de la Universidad de La Frontera. Se incluyeron la totalidad de las cohortes que han ingresado al programa, desde 2008 a 2015. Las variables de los resultados fueron: Tasa de graduación y productividad de los graduados (publicaciones WoS y SciELO). Otras variables de interés fueron: productividad del Claustro (publicaciones WoS y SciELO); y características de los alumnos que ingresaron al programa (edad, sexo, origen, profesión, formación de postgrado previa y número de años de formación universitaria formal). Se aplicó estadística descriptiva. Durante el período evaluado, de un total de 17 habilitados, se graduaron 8 doctores (1,6 por año), tasa de graduación de 47,1\%. La productividad para el período 2010-2015 fue de 14,1 publicaciones por graduado (8,4 WoS y 5,7 SciELO); y 43,8 publicaciones por miembro del Claustro (41,2 WoS y 2,6 SciELO). En el período analizado postularon 55 profesionales, siendo aceptados un total de 27 (49,1\% de aceptación). Se presentan los resultados iniciales del programa de Doctorado en Ciencias Médicas de la Universidad de La Frontera.

PALABRAS CLAVE: Educación de postgrado; Educación médica; Educación odontológica; Educación médica continua; Programas de doctorado; Programas postdoctorales.

\section{REFERENCES}

Bellissima, V.; Borghesi, A.; Bozzetti, V.; Dessì, A.; Fabiano, A.; Risso, F. M.; Salvo, V.; Satriano, A.; Silvagni, D.; Varrica, A.; van Bel, F.; Visser, G. H.; Vles, H. J.; Zimmermann, L. J.; Gavilanes, A. D. \& Gazzolo, D. Italia-Netherland PhD Program: the I.O. PhD Research Program. J. Matern. Fetal Neonatal. Med., 24 Suppl. 1:111-3, 2011.

Benderly, B. L. Not your father's postdoc. Science, 308(5722):717$8,2005$.

Bills, J. L.; Davidson, M. \& Dermody, T. S. Effectiveness of a clinical intervention for $\mathrm{MD} / \mathrm{PhD}$ students re-entering medical school. Teach. Learn. Med., 25(1):77-83, 2013.

Comisión Nacional de Acreditación CNA-Chile. Sitio Web. Santiago de Chile, Comisión Nacional de Acreditación CNA-Chile, 2015. Disponible en: https://www.cnachile.cl

Garrison, H. H. \& Gerbi, S. A. Education and employment patterns of U.S. Ph.D.'s in the biomedical sciences. F. A. S. E. B. J., 12(2):139-48, 1998

Gill, D.; Griffin, A.; Woolf, K. \& Cave, J. Twelve tips for studying medical education at doctoral level. Med. Teach., 31(7):6014, 2009 .

Gonzalez, H. \& Jiménez, A. Inserción laboral de nuevos investigadores con grado de doctor en Chile. J. Technol. Manag. Innov., 9(4):132-48, 2014.

Gould, D. J. Avoiding the postdoctoral glut: an alternative route to a career in academia. Clin. Anat., 13(6):453-5, 2000.

Jeffe, D. B. \& Andriole, D. A. A national cohort study of MD-PhD graduates of medical schools with and without funding from the National Institute of General Medical Sciences' Medical Scientist Training Program. Acad. Med., 86(8):953-61, 2011.

Jeffe, D. B.; Andriole, D. A.; Wathington, H. D. \& Tai, R. H. The emerging physician-scientist workforce: demographic, experiential, and attitudinal predictors of MD-PhD program enrollment. Acad. Med., 89(10):1398-407, 2014.

Korn, D. The postdoctoral workforce. Science, 304(5670):516, 2004.

Kuehnle, K.; Winkler, D. T. \& Meier-Abt, P. J. Swiss national MDPhD-program: an outcome analysis. Swiss Med. Wkly., 139(3738):540-6, 2009.

Lorden, J. F.; Kuh, C. V. \& Voytuk, J. A. (Eds.). Research-Doctorate Programs in the Biomedical Sciences: Selected Findings from the NRC Assessment. Washington D. C., The National Academies Press, 2011. Disponible en: http://www.nap.edu/ catalog/13213/research-doctorate-programs-in-thebiomedical-sciences-selected-findings-from

Manterola, D. C. Medicina basada en la evidencia o medicina basada en pruebas I: Generalidades acerca de su aplicación en la práctica clínica cotidiana. Rev. Med. Clin. Condes, 20(1):125-30, 2009.

Manterola, C. \& Astudillo, P. Checklist for reporting of descriptive observational studies. MINCIR Initiative. Int. J. Morphol., 31(1):115-20, 2013.

Menezes, P.; Senkomago, V. \& Coniglio, D. Physician assistant students' attitudes towards a clinical doctoral degree. $J$. Physician Assist. Educ., 26(1):3-9, 2015. 
MANTEROLA, C.; OTZEN, T. ; CARTES-VELÁSQUEZ, R.; DEL SOL, M.; OLATE, S.; ROMERO, F. \& ASTUDILLO, P. Initial results of a doctorate in medical sciences program in a regional university. Int. J. Morphol., 34(3):1169-1175, 2016.

Moses, H. 3rd; Matheson, D. H.; Cairns-Smith, S.; George, B. P.; Palisch, C. \& Dorsey, E. R. The anatomy of medical research: US and international comparisons. JAMA, 313(2):174-89, 2015 .

Oliveira, R. V.; Campos, P. C. \& Mourão, P. A. An MD-PhD program in Brazil: students' concepts of science and of common sense. Braz. J. Med. Biol. Res., 44(11):1105-11, 2011.

O'Mara, R. J.; Hsu, S. I. \& Wilson, D. R. Should MD-PhD programs encourage graduate training in disciplines beyond conventional biomedical or clinical sciences? Acad. Med., 90(2):161-4, 2015.

Pontificia Universidad Católica de Chile. Doctorado en Ciencias Médicas. Santiago de Chile, Pontificia Universidad Católica de Chile, 2016. Disponible en: http://medicina.uc.cl/doctorado/ciencias-medicas

Rosenberg, L. E. The physician-scientist: an essential--and fragile-link in the medical research chain. J. Clin. Invest., 103(12):1621-6, 1999.

Singer, M. Education. The evolution of postdocs. Science, 306(5694):232, 2004

Twa, D. D.; Squair, J. W.; Skinnider, M. A. \& Ji, J. X. The Canadian clinician-scientist training program must be reinstated. J. Clin. Invest., 125(12):4317-9, 2015.

Universidad Austral de Chile. Dirección de Estudios de Postgrado. Valdivia, Universidad Austral de Chile, 2016. Disponible en: http://www.postgrado.uach.cl/postgrado/ i n d e x.ph p ? o p t i o n = c o m _ c o n t e n t \& view $=$ article $\& i d=154 \&$ Itemid $=203 \&$ lang $=e s$

Universidad de Chile. Doctorados. Santiago de Chile, Facultad de Medicina, Universidad de Chile, 2016. Disponible en: http:// www.uchile.cl/postgrados/10286/ciencias-medicas-y-especialidad

Valdés, S. G.; Armas, M. R. \& Reyes, B. H. Principales características de la investigación biomédica actual, en Chile. Rev. Med. Chile., 140(4):484-92, 2012.

Vujaklija, A.; Hren, D.; Sambunjak, D.; Vodopivec, I.; Ivanis, A.; Marusic', A. \& Marusic', M. Can teaching research methodology influence students' attitude toward science? Cohort study and nonrandomized trial in a single medical school. J. Investig. Med., 58(2):282-6, 2010.

\author{
Correspondence to: \\ Dr. Carlos Manterola \\ Departamento de Cirugía y CEMyQ \\ Universidad de La Frontera \\ Temuco \\ CHILE
}

Telephone: $56-45-2325760$

Fax: $\quad$ 56-45-2325761

Email: carlos.manterola@ufrontera.cl

Received: 11-05-2016

Accepted: 14-07-2016 